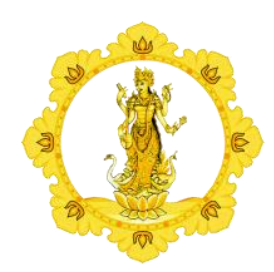

KALANGWAN

JURNAL PENDIDIKAN AGAMA, BAHASA DAN SASTRA

Vol. 10 No. 1 Maret 2020

\begin{tabular}{|c|c|l|}
\hline p-ISSN : 1979-634X & e-ISSN : 2686-0252 & http://ejournal.ihdn.ac.id/index.php/Kalangwan
\end{tabular}

\title{
NILAI PENDIDIKAN KARAKTER YANG TERKANDUNG DALAM TEMBANG BALI
}

\author{
Oleh : \\ I Gusti Ngurah Arya Putra \\ Institut Hindu Dharma Negeri Denpasar \\ E-mail: nguraharya028@gmail.com
}

Diterima 23 Januari 2020, direvisi 11 Pebruari 2020, diterbitkan 31 Maret 2020

\begin{abstract}
Masyarakat Bali dalam hidupnya tak pernah terlepas dengan sebuah sastra. Dalam sastra itu sendiri memiliki beberapa bentuk yaitu Gancaran, Tembang, dan Palawakya. Tembang (Prawiradisastra,1991:64) yaitu seni suara yang dibangun dari bermacam-macam laras dan nada sebagai bahannya. Tembang yang dikenal masyarakat bali yaitu sekar rare, sekar alit, sekar madya, sekar agung dan tembang pop bali pun juga termasuk yang sangat digemari. Dengan adanya tembang membantu dalam transfer nilai pendidikan karakter. Nilai karakter ialah suatu penggabungan dalam pengelolaan pemikiran, sikap maupun budi pekerti dalam menentukan apa yang baik dilakukan maupun yang tidak baik dilakukan, dalam bentuk permikiran, perkataan maupun perbuatan sehingga terciptanya sifat atau pribadi individu yang khas. Diharapkan agar tembang ini bukan hanya sebagai sarana pelipur lara atau penuangan ekspresi jiwa tetapi mampu berguna sebagai sarana penanaman nilai pendidikan karakter bagi seseorang. Jenis penelitian ini yaitu kualitatif dengan menggunakan metode analisis.
\end{abstract}

Keywords: Tembang, Nilai Pendidikan Karakter

\section{PENDAHULUAN}

Manusia merupakan mahluk yang lengkap dibekali oleh pemikiran, tenaga, dan suara sehingga secara harfiah manusia dikatakan sebagai mahkluk yang kompleks. Dengan apa yang dimiliki manusia mampu membuat sesuatu hal yang mampu berguna dalam memenuhi kebutuhan hidup atau berguna dalam membuat suatu karya sebagai tempat peluapan ekspresi jiwa. Dengan ekspresi jiwa ini dapat membentuk suatu kebudayaan. 
Menurut Geertz (1992:5) kebudayaan adalah 'pola dari pengertian-pengertian atau makna yang terjalin secara menyeluruh dalam simbol-simbol yang di transformasikan secara historis, suatu sistem mengenai konsepsikonsepsi yang diwariskan dalam bentukbentuk simbolik yang dengan cara tersebut manusia berkomunikasi, melestarikan dan mengembangkan pengetahuan dan sikap mereka terhadap kehidupan'. Bentuk-bentuk simbolik yang dimaksud itu ada berupa secara lisan maupun tulisan. Bentuk-bentuk simbolik yang dimaksud salah satu contohnya yaitu sastra.

Sastra adalah pengejawantahan jiwa dan perasaan manusia yang dituangkan dalam keindahan bahasa (Sudiara, 2005:3). Sastra dalam hal ini adalah bahasa yang dituangkan dengan nilai estetika yang menggambarkan kehidupan masyarakat, karya sastra tercipta sebagai perpaduan antara pengalaman lahir dan batin pengarang yang diramu dengan bahasa yang imajinatif. Kumpulan atau halhal yang berkenaan dengan sastra yaitu kesusastran. Kesusastraan Bali menurut Tinggen (1982:27) memaparkan bahwa masyarakat bali mengelompokkan menjadi dua bagian yaitu Kesusastraan Bali Purwa dan Kesusastraan Bali Anyar. Menurut bentuknya kesusastraan bali dapat dibagi menjadi tiga bagian yaitu gancaran (prosa), tembang, dan palawakya (prosa liris).

Salah satu bentuk yang menarik ditelaah yaitu tembang. Tembang adalah (Prawiradisastra,1991:64) yaitu seni suara yang dibangun dari bermacam-macam laras dan nada sebagai bahannya. Tembang yang dikenal masyarakat bali yaitu sekar rare, sekar alit, sekar madya, sekar agung dan tembang pop bali pun juga termasuk yang sangat digemari dewasa ini. Peran tembang ini yaitu sebagai alat mengungkapkan ekspresi batin, maupun berperan sebagai tempat penanaman nilai pendidikan karakter bagi pendengarnya.

\section{PEMBAHASAN}

Nilai adalah suatu kualitas atau penghargaan terhadap sesuatu, yang dapat menjadi dasar penentu tingkah laku seseorang
Bambang Daroeso (1986:20) begitu juga menurut pendapat Fraenkel sebagaimana yang dikutip oleh Soenarjati Moehadjir dan Cholisin (1989:25) nilai pada dasarnya disebut sebagai standar penuntun dalam menentukan sesuatu baik itu, indah, berharga atau tidak.

Karakter merupakan sifat dasar yang pada dasarnya dimiliki dalam diri seseorang yang menjadi identitas bagi dirinya serta dapat dirubah melalui lingkungan tempat tinggalnya ataupun pembiasaan-pembiasaan sejak dini. Karakter atau watak juga dimaknai dengan sifat batin yang mempengaruhi segenap pikiran, perilaku, budi pekerti, dan tabiat yang dimiliki setiap individu yang berguna untuk hidup dan bekerjasama baik dalam keluarga, masyarakat maupun bangsa dan negara. Individu yang memiliki karakter yang baik ialah individu yang mampu mengelola baik itu sikap, pola pikir, budi pekerti yang sesuai dengan norma yang ada dalam suatu lingkungan. Karakter adalah perilaku yang tampak dalam kehidupan sehari-hari baik dalam bersikap maupun bertindak (Samani dan Hariyanto, 2012 : 4142). Dapat disimpulkan nilai karakter ialah suatu penggabungan dalam pengelolaan pemikiran, sikap maupun budi pekerti dalam menentukan apa yang baik dilakukan maupun yang tidak baik dilakukan, dalam bentuk permikiran, perkataan maupun perbuatan sehingga terciptanya sifat atau pribadi individu yang khas.

\section{Menurut Undang-Undang Dasar} 1945 tujuan pendidikan yang ingin dicapai dalam pembukaan alenia ke-4 yaitu "mencerdaskan kehidupan bangsa". Sedangkan dalam Undang-Undang Nomor 20 tahun 2003 Tentang Sistem Pendidikan Nasional (Sisdiknas) menyatakan tujuan pendidikan nasional adalah mengembangkan potensi peserta didik agar menjadi manusia yang beriman dan bertakwa kepada Tuhan Yang Maha Esa, berakhlak mulia, sehat, berilmu, cakap, kreatif, mandiri, dan menjadi warga negara yang demokratis serta bertanggung jawab. Jikalau dilihat relasi dengan kurikulum 2013 bersifat relevan yaitu 
mengedepankan aspek afektif (sikap). Berdasarkan dengan Undang-Undang Nomor 20 tahun 2003 dan kurikulum 2013 menghasilkan delapan belas karakter yang harus dapat dibentuk sehingga menjadi individu yang berkualitas yaitu religius, jujur, disiplin, toleransi, kerja keras, kreatif, mandiri, demokratis, rasa ingin tahu, semangat kebangsaan, cinta tanah air, menghargai prestasi, komunikatif, cinta damai, gemar membaca, peduli lingkungan, peduli sosial, tanggung jawab.

Masyarakat bali erat hubungannya dengan tembang karena dapat dikatakan dari bayi hingga mati dihantarkan dengan lagu. Klasifikasi tembang bali meliputi: (1) gegendingan (gending raré, gending jangér, gending sangiang; (2) sekar macapat atau sekar alit seperti pupuh-pupuh; (3) sekar madia atau tembang tengahan seperti kidung; dan (4) sekar agung atau tembang gedé seperti wirama. Selanjutnya, tembang Bali modern adalah lagu-lagu pop Bali.

\section{A. Sekar Rare}

Sekar rare merupakan bagian dari gegendingan, yaitu jenis tembang Bali yang bahasanya sederhana dan diperuntukkan bagi anak-anak usia dini sampai pada tingkat sekolah dasar. Salah satu contoh sekar rare yaitu "Cening Putri Ayu"

Cening putri ayu, ngijeng cening jumah

Meme luas malu, ke peken meblanje Apang ade daharan nasi

Meme tiang ngiring, nongos ngijeng jumah

Sambilan mekumpul, ajak titiang dadue

Ditekani nyenggap gagapin

Pelalian cening kotak wadah gerip Jaja magenepan sane luwung luwung Bunga melah-melah ambunyane sarwa miyik

\section{Terjemahannya:}

Putri cening ayu, diamlah nanda di rumah, ibu pergi dahalu, ke pasar berbelanja, agar ada dimakankan nasi.

Ibu saya sanggup, saya menunggu di rumah, sambil mengasuh adik, saya berdua, pulangnya, tolong bawakan oleholeh.

\section{Mainan nanda kotak tempat gerip} Banyak jajan yang enak-enak Bunga serba indah aromanya serba harum

Berdasarkan uraian diatas, maka tembang Cening Putri Ayu memiliki beberapa nilai karakter yang tersirat didalamnya. Adapun uraiannya adalah sebagai berikut :

\section{1) Tanggung Jawab dan Disiplin}

Nilai tanggung jawab dan disiplin yang tersirat dalam tembang ini dimana seorang putri yang memiliki kepedulian terhadap orang tua, dengan tinggal dirumah berkumpul dengan saudara sambil mengasuh adiknya.

\section{2) Kreatif}

Nilai kreatif disini ialah seorang anak menggunkan kotak tempat gerip sebagai mainannya rikala menunggu ibunya datang. Dalam hal ini menunjukkan bahwa seorang anak memliki pola pikir yang baik dengan tidak adanya mainan mampu menggunakan barang biasa sebagai hiburan bagi dirinya.

\section{B. Sekar Alit}

Sekar Alit di Bali tembang macapat sering disebut dengan pupuh yang berarti rangkaian tembang (Budiyasa dan Purnawan 1998:8). Pupuh merupakan bentuk puisi tradisional yang memiliki jumlah suku kata dan irama tertentu di setiap barisnya. 
Pupuh sendiri diikat dengan aturan "pada dan lingsa". Adapun pupuh dalam sekar alit yaitu sinom, semarandana, dangdang, pangkur, pucung, mijil, ginanti, ginada, durma, seta maskumambang . salah satu contoh sekar alit yang memiliki nilai karakter yaitu "Pupuh Ginanti"

Saking tuhu manah guru, mituturin cening jani, kawruhane luir senjata, ne dadi prabotang sai, kaanggen ngaruruh merta, saenun ceninge urip.

\section{Terjemahannya:}

Dengan serius pikiran seorang guru, menasihati nanda sekarang, pengetahuan itu bagaikan senjata,

yang bisa dipat diperalat sehari-hari,

dipakai mencari nafkah, selagi ayat dikandung badan.

Berdasarkan uraian diatas tersirat nilai pendidikn karakter yang terkandung dalam lagu ini yaitu :

\section{Kerja Keras}

Menurut (Dharma Kesuma, dkk 2011:17) kerja keras adalah suatu istilah yang melingkupi suatu upaya yang terus dilakukan dalam menyelesaikan pekerjaan/tugas sampai tuntas. Bagaimana agar seseorang meliki sikap kerja keras,disiplin dan memiliki rasa ingin tahu dalam menuntut ilmu agar mampu tercapai yang diharapkan.

\section{Komunikatif}

Sikap komunikatif disini ialah sikap atau tindakan yang mendorong dirinya untuk menghasilkan sesuatu yang berguna bagi masyarakat. Dalam hal ini bagaimana seorang guru memberikan motivasi atau nasehat sehingga dengan nasehat tersebut mampu membuat seseorang termotivasi menjadi semangat dalam belajar agar tercapai apa yang dicita-citakan.

\section{Sekar Madya}

Sekar madya yang meliputi jenis-jenis lagu pemujaan, umumnya dinyanyikan dalam prosesi upacara, baik upacara adat maupun agama. Kelompok tembang yang tergolong sekar madya pada umumnya mempergunakan bahasa Jawa Tengahan. Adapun salah satu contoh tembang (sekar madya) yang terdapat nilai karakternya yaitu Kidung Kawitan Wargasari
Ida Ratu saking luhur
Kawula nunas lugrane
Mangda sampun titiang tandruh
Mangayat bhatara mangkin
Titiang ngaturang pejati
Canang suci lan daksina
Sarwa sampun puput
Pratingkahing saji

\section{Terjemahan :}

Ya tuhan engkau berasal dari tempat mu yang luhur

Hamba meminta izin kepadamu

Saat ini menyembahmu tuhan

Saya menyajiakan pejati

Canang suci dan daksina

Sudah selesai semua

Persembahan kepadamu

Berdasarkan uraian diatas nilai karakter yang tersirat dalam kidung kawitan wargasari tersebut ialah :

1. Nilai Religius dan Tanggung Jawab

Terlihat dalam kutipan tersebut yang menunjukan sikap tersebut ialah bagaimana seseorang melakukan tanggung jawab dengan melakukan yadnya dalam bentuk canang pejati dan daksina beberapa hal ini merupakan sarana persembahan kehadapan Tuhan 
sebagai bentuk rasa hormat dan bhakti.

\section{Sekar Agung}

Sekar Agung juga disebut dengan kekawin, selain itu dinamakan pula dengan wirama. Dalam melagukan kekawin ini biasanya mengkuti aturan tertentu yaitu "Mantra" aturan mantra yang dimaksud adalah guru lagu. Guru lagu adalah adanya suara berat dan panjang atau ringan dan lambat dalam tembang kekawin. Selain itu ada pula aturan kekawin yaitu "wreta" yaitu adanya suku kata kecap yang membentuk empat baris atau tiga baris menjadi satu bait dalam kekawin. Adapun salah satu contoh sekar agung yang terdapat nilai pendidikan karakter didalamnya yaitu " Wirama Merdukomala".

Ong sembah ninganatha tinghalana de tri loka sarana Wahya dhyatmika sembahing hulun ijongta tan hana waneh Sang lwir Agni sakeng tahen kadi minak sakeng dadhi kita Sang saksat metu yan hana wwang ngamuter tutur pinahayu.

\section{Terjemahan:}

Ya Tuhan sembah hamba ini orang hina, silahkan lihat oleh Mu penguasa tiga dunia, Lahir batin sembah hamba kehadapan kaki Mu tiada lain, Engkau bagaikan minyak yang keluar dari santan,

Engkau seakan-akan nyata tampak apabila ada orang yang mengolah ilmu batin dengan baik,

Berdasarkan uraian diatas nilai pendidikan karakter yang tersirat didalamnya yaitu

\section{Nilai religius}

Seperti yang tersirat bagaimana seseorang menghaturkan sembah bhakti yang tulus tiada lain untuk Tuhan Yang Maha Esa baik dalam bentuk lahir dan batinnya. Dalam agama hindu mengenal Tri Rna dimana salah satunya berisikan Dewa Rna yaitu membayar hutang kepada dewa, hutang yang dibayar dalam bentuk sembah suci yang tulus ikhlas. Diharapkan agar setiap orang memiliki nilai religius dalam diri.

\section{E. Tembang Pop Bali}

Menurut Strinati (2009) musik pop yang sifatnya easy listening. Artinya jenis music ini bisa didengarkan begitu saja tanpa perlu perhatian khusus. Musik ini memposisikan seseorang pada realita kehidupan yang tengah mereka jalani. Dalam hal ini tembang pop bali sangat jelas menggunakan bahasa bali sebagai liriknya. Berfungsi sebagai pengungkap ekspresi pengarang, maupun berguna sebagai bentuk perekat sosial. Dalam hal ini adapun salah satu contoh tembang pop bali yang memiliki nilai pendidikan karakter didalamnya yaitu :

\section{Bunga Sandat}

Yen gumanti bajang, tan bina ya pucuk nedeng kembang,

Di suba ya layu, tan ada ngarunguang ngemasin makutang,

Becik malaksana, eda gumanti dadi kembang bintang,

Mentik di rurunge, makejang mangempok raris kaentungang,

To i bungan sandat, salayu-layu layune miik, to ya nyandang tulad saurupe malaksana becik

Para truna-truni mangda saling asah asih asuh,

Manyama beraya pakukuhin rahayu kapanggih.

Terjemahannya: 
Kalau menjadi orang bujang, tak obahnya bunga pucuk sedang mekar,

Kalau dia sudah layu, tak ada yang memperhatikan dan terbuang.

Berbuatlah yang baik, janganlah menjadi bunga kembang bintang, tumbuh di jalanan, semuanya memetik lalu dibuang.

Itulah si bunga sandat, sampai layu dia tetap harum, itulah yang patut ditiru, semasa hidupnya berbuat baik

Para muda-mudi supaya saling asah, asih, dan asuh,

Kehidupan manyama beraya dikukuhkan, akan menemui keselamatan.

Berdasarkan uraian diatas dapat dilihat bahwa nilai pendidikan karakter yang terkandung

Dalam lagu ini yaitu:

\section{Cinta Damai}

Sikap ini digambarkan dalam sebuah lagu yang yang menginginkan setiap pemuda memiliki sikap saling sayang saling mengasihi agar terciptanya suasana yang harmonis serta damai.

\section{PENUTUP}

\section{Simpulan}

Nilai karakter adalah suatu penggabungan dalam pengelolaan pemikiran, sikap maupun budi pekerti dalam menentukan apa yang baik dilakukan maupun yang tidak baik dilakukan, dalam bentuk permikiran, perkataan maupun perbuatan sehingga terciptanya sifat atau pribadi individu yang khas. Hampir dalam setiap tembang memiliki sekurang-kurangnya satu nilai pendidikan karakter yang terkandung, baik dalam sekar rare, sekar alit, sekar madya, sekar agung maupun sekar madya.

\section{Saran}

Kepada para pengarang atau pencipta lagu agar memiliki usaha menciptakan karya yang bukan hanya sebagai hiburan melainkan mampu menularkan nilai-nilai pendidikan karakter bagi para pendengarnya.

Kepada orang tua agar mampu mengawasi anaknya mendengarkan tembangtembang yang sekiranya cocok didengarkan sesuai dengan usia anak. Sehingga membantu dalam penginputan nilai-nilai pendidikan karakter.

\section{DAFTAR PUSTAKA}

http://musiklib.org/lagu_balicening_putri_ayu-lirik_lagu.htm diakses pada (25-03-2019 Pukul 10.54)

Yunus, R. (2016). Transformasi nilai-nilai budaya lokal sebagai upaya pembangunan karakter bangsa. Jurnal penelitian pendidikan,2016,13(1)

Herawan, K.D., \& Sudarsana,I.K. (2017). Relevasi Nilai Pendidikan Karakter Dalam Geguritan Suddhamala untuk meningkatkan Mutu Pendidikan Di Indonesia. Jurnal Penjamin Mutu, 3(2), 223-236

Suwija, I. N. (2012). Nilai-Nilai Pendidikan Karakter Dalam Pembelajaran Bahasa Bali. Jurnal Pendidikan Karakter, (1) 